\title{
The Impact of Intermittent Hypobaric Hypoxia Exposures on Triacylglycerol Synthesis in Rat Liver
}

\author{
Syarifah Dewi*1,2, Yulhasri Yulhasri ${ }^{1,2}$, Wawan Mulyawan ${ }^{3}$
}

\begin{abstract}
Background: In a hypoxic state, fatty acid breakdown reaction may be inhibited due to a lack of oxygen. It is likely that the fatty acids will be stored as triacylglycerol. The aim of this study was to analyse triacylglycerol synthesis in the liver after intermittent hypobaric hypoxia $(\mathrm{HH})$ exposures.

Methods: Samples are liver tissues from 25 male Wistar rats were divided into 5 groups: control group (normoxia), group I (once HH exposure), group II (twice HH exposures), group III (three-times $\mathrm{HH}$ exposures) and group IV (four-times $\mathrm{HH}$ exposures). The triacylglycerol level, mRNA expression of HIF- $1 \alpha$ and PPAR- $\gamma$ were measured in rat liver from each group.

Results: We demonstrated that triacylglycerol level, mRNA expression of HIF-1 $\alpha$ and PPAR- $\gamma$ is elevated in group I significantly compared to control group. In the intermittent HH groups (group II, III and IV), mRNA expression of HIF- $1 \alpha$ and PPAR- $\gamma$ tends to downregulate near to control group. However, the triacylglycerol level is still found increased in the intermittent $\mathrm{HH}$ exposures groups. Significant increasing of triacylglycerol level was found especially in group IV compared to control group.

Conclusions: We conclude that intermittent $\mathrm{HH}$ exposures will increase the triacylglycerol level in rat liver, supported by the increasing of HIF- $1 \alpha$ and PPAR- $\gamma$ mRNA expression that act as transcription factor to promote triacylglycerol synthesis.
\end{abstract}

Keywords: HIF-1 $\alpha$, Hypoxia, Liver, PPAR- $\gamma$, Triacylglycerol.

\section{Introduction}

Liver is the main organ for the synthesis, oxidation, metabolism, storage and distribution of lipids. Therefore, this organ plays a role in controlling lipid homeostasis in our body (1). Triacylglycerol is the major lipid molecules represent of lipid storage in cells and transportation of fatty acids in plasma. Structure of triacylglycerol consist of glycerol molecule bound to three fatty acids. Source of fatty acids in liver tissues could from the plasma or from de novo biosynthesis. Fate of fatty acids in liver is depending on the adequacy of energy in the body. If our body needs amount of ATP, fatty acids would be breakdown through oxidation- $\beta$ yield Acetyl-CoA. If the energy in our body is sufficient, then fatty acids will be stored as triacylglycerols $(1,2)$.
Acetyl-CoA resulted from oxidation- $\beta$ of fatty acid will enter the citric acid cycle then followed by oxidative phosphorylation which this reaction needs oxygen for the final electron acceptor. In hypoxic condition this pathway would be inhibited. Fate of fatty acids in the hepatocytes most likely to be synthesized into triacylglycerols in hypoxia $(3,4)$. Hypoxia inducible factors (HIFs) acts as transcription factor that regulate various cellular and molecular responses toward hypoxia, such as erythropoiesis, angiogenesis, metabolic pathways, and cell survival, by activating transcription of target genes (5). Subunit- $\alpha$ of HIFs is sensitive to oxygen deprivation, while subunit- $\beta$ is constitutive molecule. There are three isoforms of HIF $\alpha$ subunits have been 
identified: HIF-1 $\alpha$, HIF-2 $\alpha$, and HIF-3 $\alpha$ (6). Previous studies reported that hypoxia upregulates some gene expressions involved in lipogenesis, lipid uptake, and lipid droplet formation (7). Under hypoxia, uptake of extracellular fatty acids and triacylglycerol synthesis are promoted by transcription factor PPAR- $\gamma$ (peroxisome proliferator activated receptor- $\gamma$ ) (4).

Partial oxygen pressure decreases in line with increase in altitude, for example the atmospheric pressure at altitude of $5500 \mathrm{~m}$ is only $380 \mathrm{mmHg}$ (at sea level is $760 \mathrm{mmHg}$ ) which has oxygen partial pressure of inspired air is $80 \mathrm{mmHg}$ and partial oxygen pressure in alveoli is only $45 \mathrm{mmHg}$. It makes difficult for $\mathrm{O} 2$ to diffuse into the vascular system resulting in $\mathrm{O} 2$ deprivation or hypoxia which is also known as hypobaric hypoxia (HH) (8). Hypoxia exposure to human tissues or cells is responded by cellular or molecular processes by regulating some genes expression. One of the response mechanisms to hypoxia is metabolic alteration. Alteration in carbohydrate metabolism in a hypoxic state have been widely studied, whereas lipid metabolism in hypoxic state still needs to be explored further. As explained before, triacylglycerol synthesis will be increased in hypoxic state, this condition may contribute to fatty liver disease and metabolic syndrome (9).

Pilots and air force soldiers routinely perform hypobaric hypoxia training to identify hypoxia condition and make their body doing adaptation toward hypoxia. They experienced the intermittent hypobaric hypoxia. How the alteration of lipid metabolism, especially triacylglycerol synthesis in liver tissue after intermittent hypobaric hypoxia exposures is still unclear. So, in this study we want to explore the triacylglycerol synthesis in rat liver that induced by intermittent hypobaric hypoxia.

\section{Materials and Methods Study Design}

This is an experimental study using animal model (Wistar rat) conducted in Biochemistry and Molecular Biology Laboratory, Faculty of
Medicine Universitas Indonesia and Aerophysiology Laboratory in Lakespra Saryanto TNI AU. Total number of rats in this study was calculated by Federer formula are 25 male Wistar rats (6-8 weeks old with weight 150-200 g). There are 5 groups of experiment, consisting control group (normoxia, $\mathrm{n}=5$ ), group I (once $\mathrm{HH}$ exposure, $\mathrm{n}=5$ ), group II (twice $\mathrm{HH}$ exposures, $\mathrm{n}=5$ ), group III (threetimes $\mathrm{HH}$ exposures, $\mathrm{n}=5$ ) and group IV (fourtimes HH exposures, $n=5$ ). Hypobaric hypoxia exposures were conducted by placing the rats of treatment group (I-IV) into hypobaric chamber with 25.000 feet of altitude simulation for 5 minutes and it is repeated 1 week later for intermittent exposure. Protocol of hypobaric hypoxia is designed based on special training for air force soldier $(10,11)$. After exposures of each treatment group, all the rats were euthanized when it still in hypobaric chamber with 5000 feet of altitude and the liver organs were collected. Figure 1 describes the altitude simulation of this experiment. The treatment of experimental animals in this study has received ethical approval from The Ethics Committee of the Faculty of Medicine, Universitas IndonesiaCipto Mangunkusumo Hospital with no. KET774/UN2.F1/ETIK/PPM.00.02/2020.

\section{Measurement of Triacylglycerol Level in Liver Tissue}

Liver tissue was weighed as much as $100 \mathrm{mg}$ and then it is homogenized in $1000 \mu \mathrm{L}$ of PBS $0.1 \mathrm{M}$ pH 7.4. The homogenate was centrifuged at $600 \mathrm{~g}$ for $10 \mathrm{~min}$ and then take the supernatant for triacylglycerol detection. We measured triacylglycerol level using Triglyceride Colorimetric Assay Kit (Elabscience $\left.{ }^{\circledR}\right)$ and we conducted according to manual instruction from the factory. The principle of this kit is triacylglycerol will be breakdown into glycerol and fatty acids. The glycerol is converted into glycerol-3 phosphate which then converted into hydroxyacetone phosphate and $\mathrm{H} 2 \mathrm{O} 2$ by glycerol-3 phosphate oxidase. The last is parachlorphenol can react with $\mathrm{H} 2 \mathrm{O} 2$ results red quinone which is directly proportional to the triglyceride 
content. The result number of this measurement was divided by total protein concentration, so the unit of triacylglycerol levels is presented in $\mathrm{mg} / \mathrm{g}$ protein.

\section{Extraction of total RNA from Liver Tissue}

Total mRNA of liver tissues was extracted using Quick-RNA ${ }^{\text {TM }}$ MiniPrep Plus Kit (Zymo Research) and conducted according to manual instruction from the factory. The concentration of RNA was measured by reading the absorbance at $260 \mathrm{~nm}$ using spectrofluorometer (Varioskan ${ }^{\mathrm{TM}}$, Thermo Scientific). The RNA samples are stored in -80 ${ }^{\circ} \mathrm{C}$ freezer until used for real time qPCR.

\section{Measurement of Relative mRNA Expression of HIF-1 $\alpha$ and PPAR- $\gamma$}

Relative mRNA expression of HIF-1 $\alpha$ and PPAR- $\gamma$ was measured using one-step real time qPCR. The amount of RNA is $100 \mathrm{ng}$ for each sample. We used SensiFAST ${ }^{\text {TM }}$ SYBR ${ }^{\circledR}$ No-ROX One-Step Kit (Bioline) for PCR mixture reagents and Applied Biosystems ${ }^{\circledR}$ 7500 Fast Real-Time PCR System for qPRC machine. The PCR cycle consist $45{ }^{\circ} \mathrm{C}$ incubation for 10 minutes initially, followed by a 2 -minute incubation at $95^{\circ} \mathrm{C}$ and then 40 cycles of $95{ }^{\circ} \mathrm{C}$ for 5 seconds, $60{ }^{\circ} \mathrm{C}$ for 30 seconds, $72{ }^{\circ} \mathrm{C}$ for 30 seconds and the last is melting curve incubation from $60{ }^{\circ} \mathrm{C}$ until 95 ${ }^{\circ} \mathrm{C}$. The 18 sRNA gene used as housekeeping gene. The relative expression is calculated using Livak formula, by compare $\mathrm{Ct}$ value of treatment group to control group.(12) Primer sequences of HIF- $1 \alpha$ are 5'- TCA AGT CAG CAA CGT GGA AG -3' as forward, 5'- TAT CGA GGC TGT GTC GAC TG -3 ' as reverse and it yield PCR product 198 bp. Primer sequences of PPAR- $\gamma$ are 5'- TCT GGG AGA TCC TCC TGT TGA -3' as forward, 5'- CGA AGT TGG TGG GCC AGA AT -3' as reverse and it yield PCR product $119 \mathrm{bp}$.

\section{Statistical Analysis}

Data from this study was analyzed by statistical test using SPSS statistics software version 20.0. The normality test was performed using Shapiro-Wilk analysis, to know the data was normal distributed or not. Number result each parameter was analyzed by independent $t$ test to compare means of each experiment group to control group. Significancy different was determined if $p$ value $<0.05$.

\section{Results}

We demonstrated that triacylglycerol levels in liver tissue were elevated both after $\mathrm{HH}$ one time exposure (group I) as well as intermittent $\mathrm{HH}$ exposure (group II, III and IV) compared to control group (Fig. 2). Triacylglycerol levels in group I $(33.711 \pm 4.884 \mathrm{mg} / \mathrm{g}$ protein) was significantly increasing $(\mathrm{p}<0.05$, independent $\mathrm{t}$ test) compared to control group $(19.227 \pm 2.841 \mathrm{mg} / \mathrm{g}$ protein). Triacylglycerol levels in group II $(29.542 \pm 4.147 \mathrm{mg} / \mathrm{g}$ protein) and group III ( $31.987 \pm 8.549 \mathrm{mg} / \mathrm{g}$ protein) was also elevated although not significant compared to control group. We found triacylglycerol levels was significantly increasing in group IV $(40.357 \pm 0.7091 \mathrm{mg} / \mathrm{g}$ protein) compared to control group ( $\mathrm{p}<0.05$, independent $\mathrm{t}$ test).

We also measured molecular regulator in hypoxia state, HIF-1 $\alpha$. Relative mRNA expression of HIF- $1 \alpha$ in group I $(1.845 \pm 0.179)$ and group II $(1.735 \pm 0.184)$ were significantly increasing $(\mathrm{p}<0.05$, independent $t$ test $)$ compared to control group $(1.012 \pm 0.075)$. Relative mRNA expression of HIF- $1 \alpha$ in group III (1.144 \pm 0.183$)$ and group IV (1.237 \pm 0.093$)$ were still increased than control group although it is not significant (Fig. 3).

We measured the mRNA expression of PPAR- $\gamma$, a transcription factor which regulates triacylglycerol synthesis. We found the relative mRNA expression of PPAR- $\gamma$ in group I $(2.948 \pm 0.961)$ and group II $(2.569 \pm 0.877)$ were increasing compared to control group $(1.220 \pm 0.419)$ although it is not significant. Relative mRNA expression of HIF- $1 \alpha$ in group III (1.231 \pm 0.148$)$ and group IV (1.264 \pm 0.258$)$ were not different to control group expression (Fig. 4). 


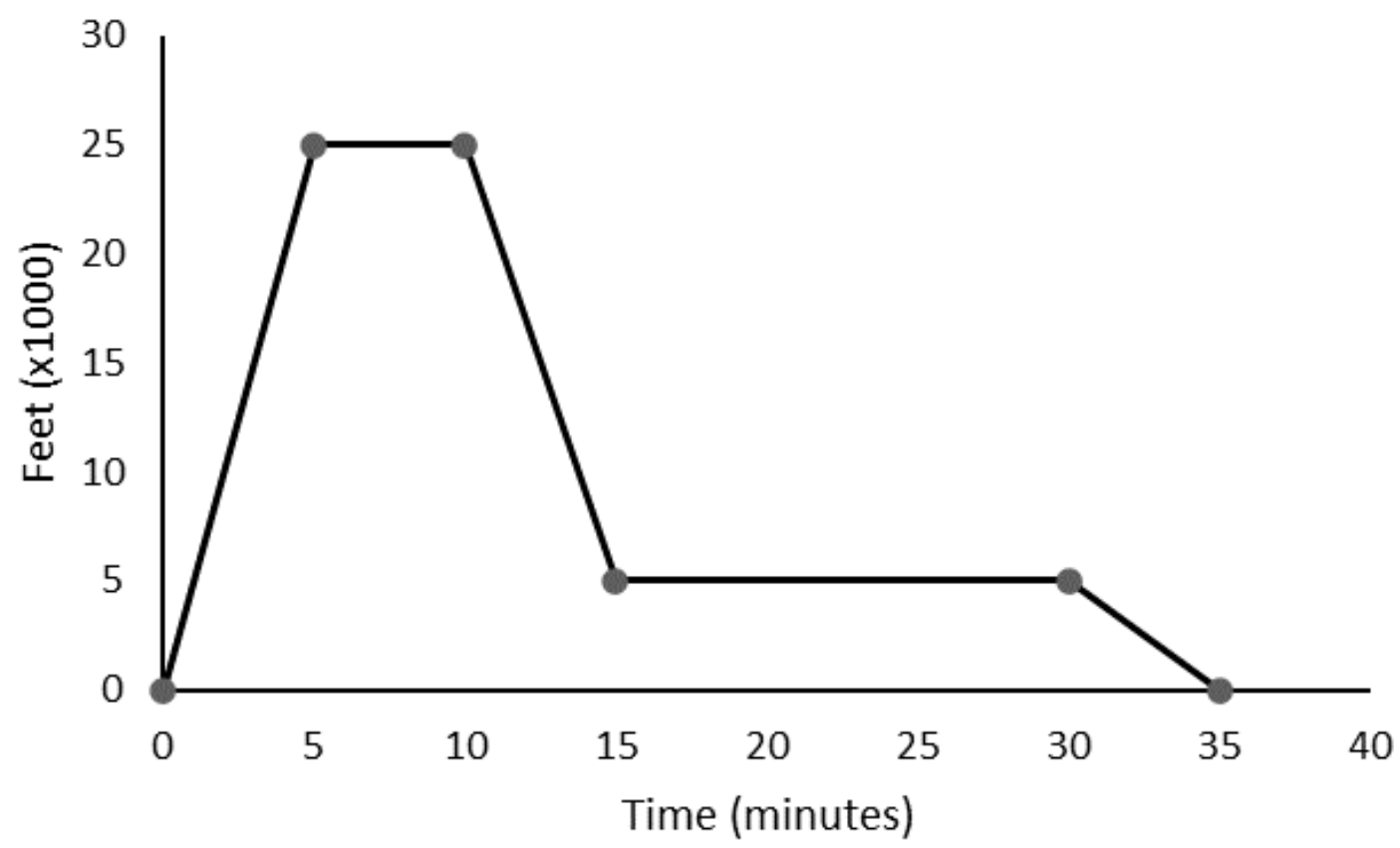

Fig. 1. Altitude simulation treatment using a hypobaric chamber. Hypoxic exposure is achieved in altitude of 25,000 feet for 5 minutes, rats were sacrificed at 5000 feet.

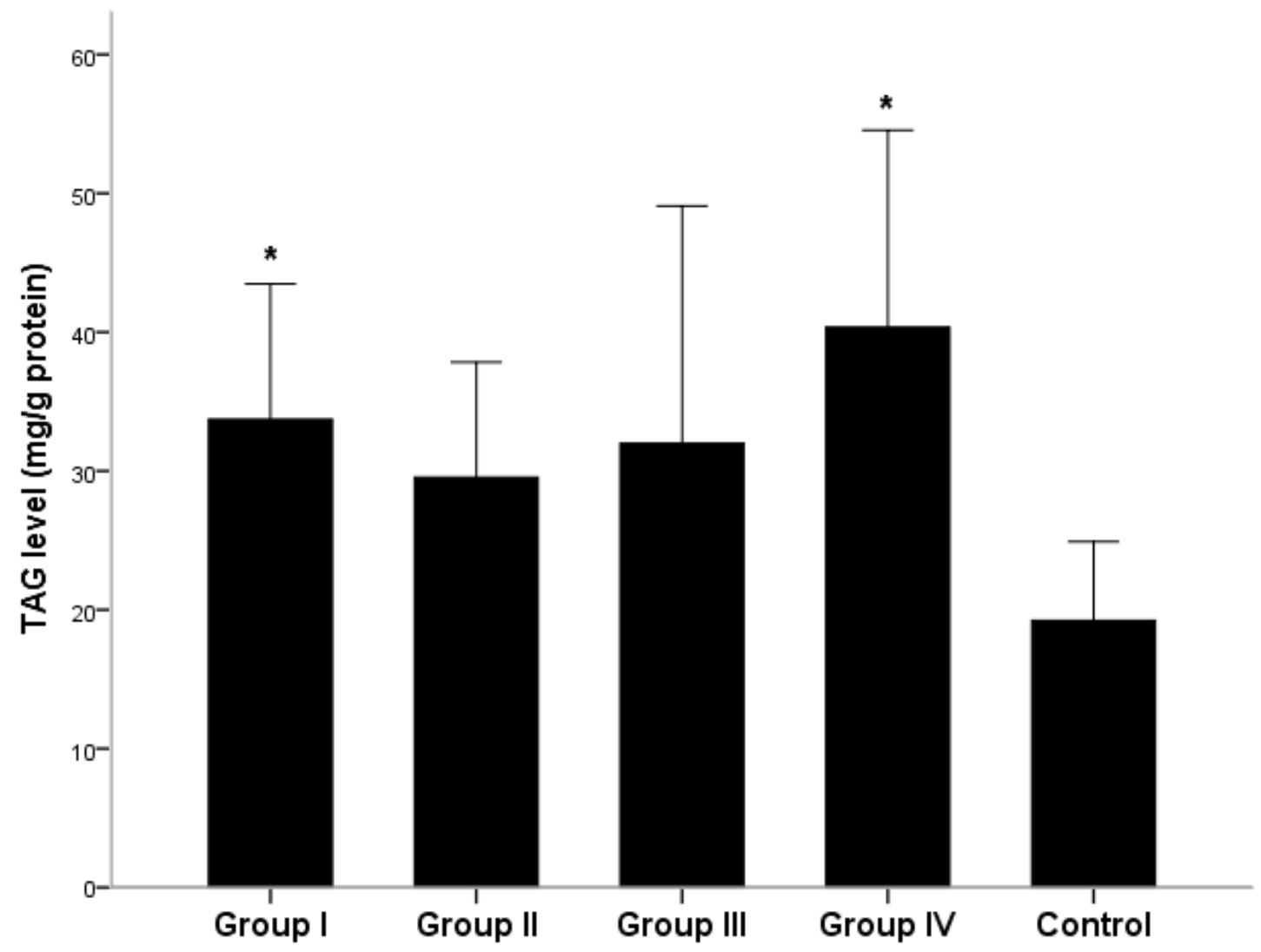

Fig. 2. Triacylglycerol levels in rat liver tissues after intermittent hypobaric hypoxia exposures. Group I (once HH exposure, $n=5$ ), group II (twice HH exposures, $n=5$ ), group III (three-times HH exposures, $n=5$ ), group IV (four-times HH exposures, $n=5$ ), control group (normoxia, $n=5)$. Significant difference compared to control group $(* p<0.05)$ by independent $t$ test. 


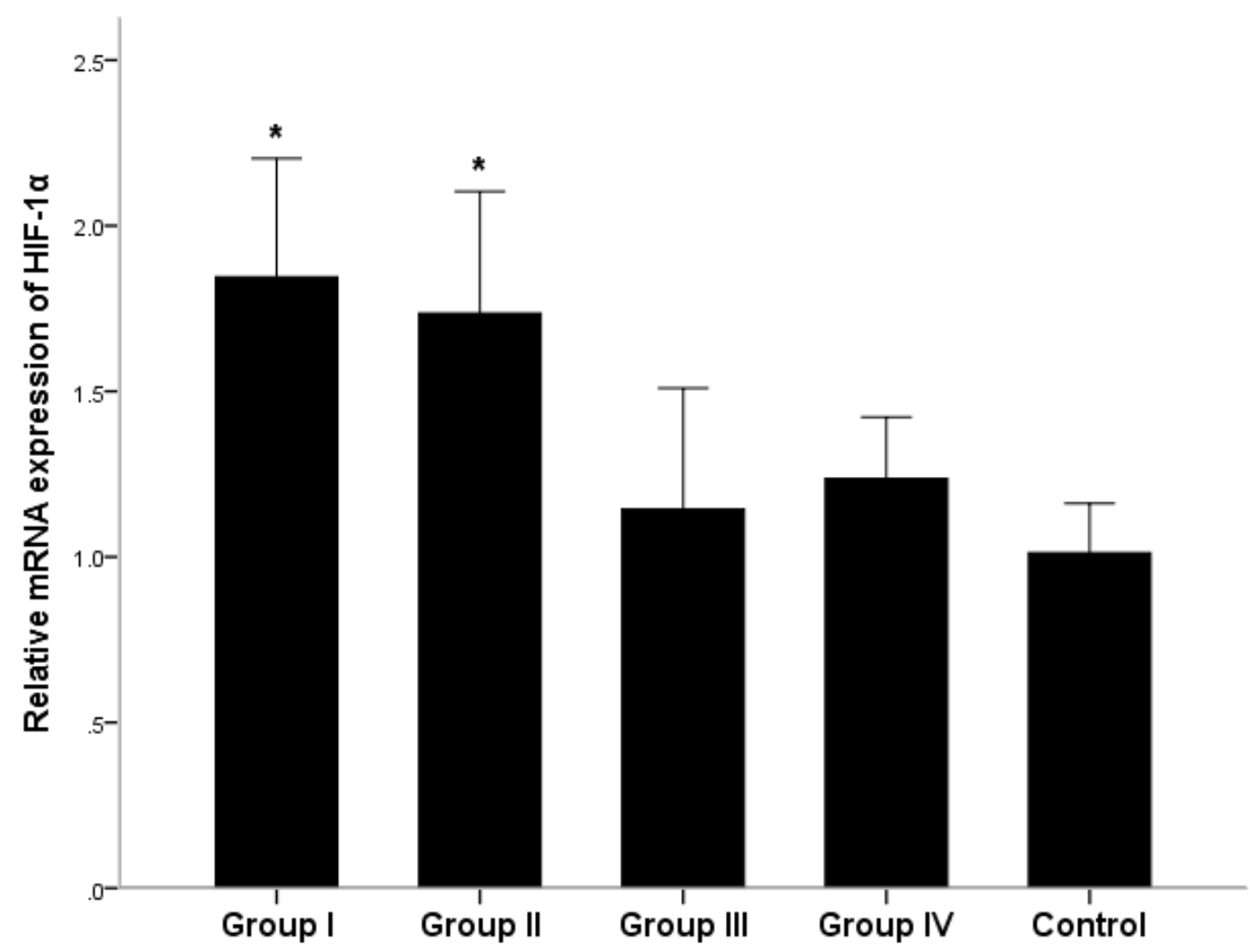

Fig. 3. Relative mRNA expression of HIF-1 $\alpha$ in rat liver tissues after intermittent hypobaric hypoxia exposures. Group I (once HH exposure, $n=5$ ), group II (twice HH exposures, $n=5$ ), group III (three-times HH exposures, $n=5$ ), group IV (four-times $\mathrm{HH}$ exposures, $\mathrm{n}=5$ ), control group (normoxia, $\mathrm{n}=5$ ). Significant difference compared to control group $(* \mathrm{p}<$ 0.05 ) by independent $t$ test.

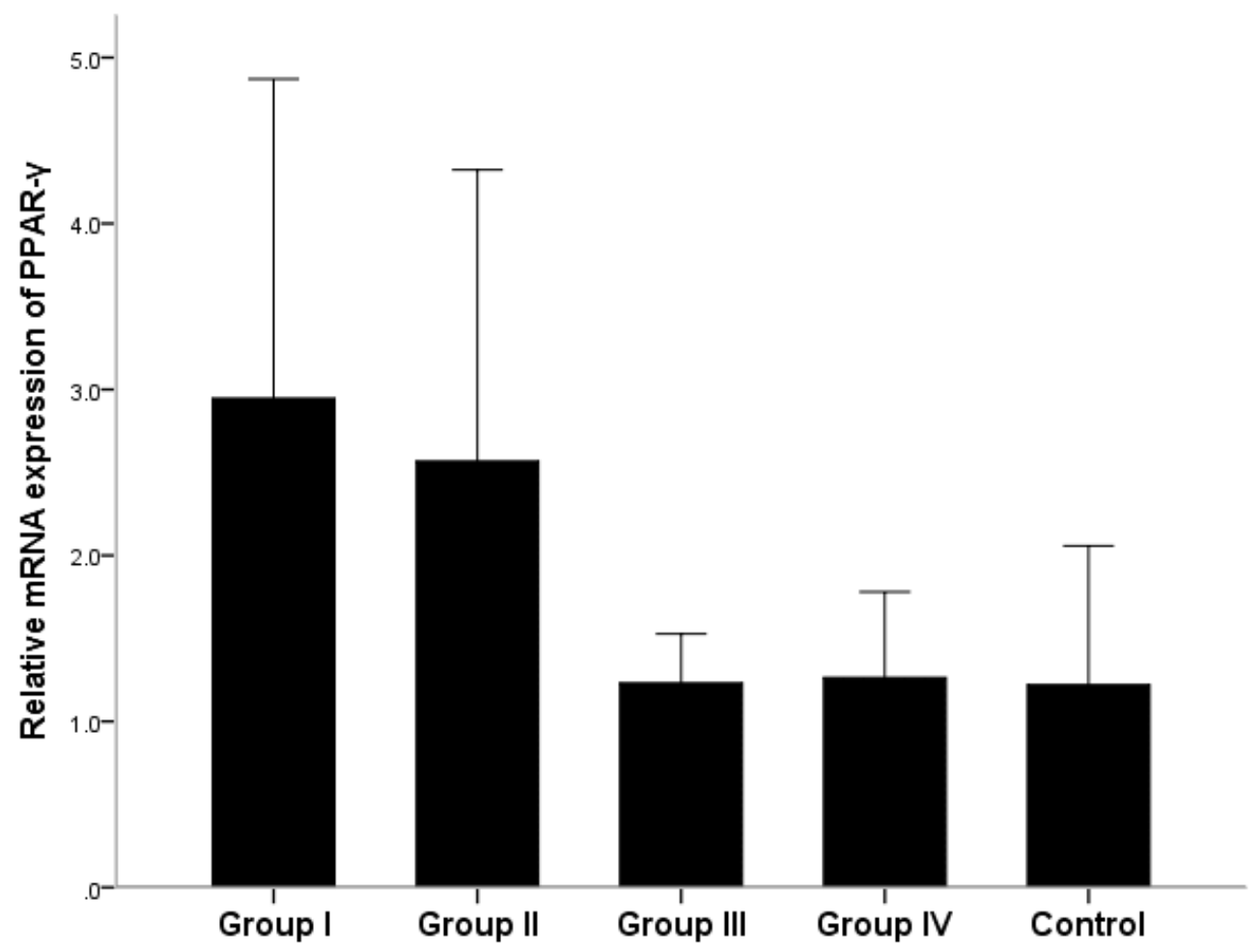

Fig. 4. Relative mRNA expression of PPAR- $\gamma$ in rat liver tissues after intermittent hypobaric hypoxia exposures. Group I (once HH exposure, $n=5$ ), group II (twice HH exposures, $n=5$ ), group III (three-times HH exposures, $n=5$ ), group IV (four-times $\mathrm{HH}$ exposures, $\mathrm{n}=5$ ), control group (normoxia, $\mathrm{n}=5$ ). 


\section{Discussion}

Our findings in this study demonstrated that there was significant increasing of triacylglycerol level in rat liver after $\mathrm{HH}$ exposure compared to control group. After intermittent $\mathrm{HH}$ exposure (group II-IV), triacylglycerol level was still higher than control, especially in group IV has significantly increasing. These results show that intermittent $\mathrm{HH}$ exposures will increase triacylglycerol level in rat liver. Other studies reported that hypoxia will induce accumulation of lipid droplets by activation of AGPAT2 (acylglycerol-3-phosphate acyltransferase 2) and lipin-1 (phosphatidic acid phosphohydrolase) which are the enzymes involved in triacylglycerol synthesis pathway $(13,14)$. AGPAT2 or also known as LPAAT (lysophosphatidic acid acyltransferase), converts lysophosphatidic acid to phosphatidic acid, while lipin-1 converts phosphatidic acid to diacylglycerol in triacylglycerol synthesis. Both AGPAT2 and lipin-1 is induced by transcription factor PPAR- $\gamma$ activated-HIF1 $(13,15)$.

In this study, we demonstrated relative mRNA expression of HIF-1 $\alpha$, as key regulator molecule in hypoxic condition, was significantly increasing in once $\mathrm{HH}$ (group I) and twice $\mathrm{HH}$ (group II) exposures compare to control group. The more intermittent exposure (group III and IV) will not increase the HIF-1 $\alpha$ mRNA expression. This is caused by the adaptation has been occurred in hepatocyte towards hypoxia. Repeated or intermittent exposures to hypoxia condition could make the cells adapt towards hypoxia (16). We also found the relative mRNA expression of PPAR$\gamma$ was increased in group I and II, after that the PPAR- $\gamma$ expression was decline (group III and IV) near to control group. These results suggest that hepatic triacylglycerol synthesis in a hypoxic state may be regulated by the transcription factor PPAR- $\gamma$, which is the target of HIF1 (17). Some previous studies have revealed that PPAR- $\gamma$ plays an important role in regulating triacylglycerol synthesis and secretion in goat mammary cells (18) and it is considered as a factor transcription for adipocyte differentiation $(19,20)$.

Previous study demonstrated that the increasing of PPAR $\gamma$ mRNA and protein levels in line with the increasing of HIF-1 protein levels in HepG2 cells in hypoxia condition (17). Another study reported that HIF-1 $\alpha$ induces glycolytic genes and $\operatorname{PPAR} \gamma$, which these changes lead increasing of glycolytic flux and glucose-to-lipid conversion via the glycerol-3-phosphate pathway in cardiomyocytes.(21) Some studies also reported that PPAR $\gamma$ is upregulated in patients with non-alcoholic fatty liver disease (NAFLD) and promotes lipogenesis in the liver tissues $(22,23)$. An in vitro study proved that the inhibition of adipogenesis through downregulation of PPAR $\gamma, \operatorname{CEBP} \alpha$ that decreased of acetyl-CoA carboxylase and fatty acid synthase enzymes.(24) Moreover, there is an inhibition of lipid degradation pathways in hypoxia because HIF-1 $\alpha$ will downgrade fatty acid oxidation through the inhibition of carnitine palmitoyl transferase 1 (CPT1A) and acyl-CoA dehydrogenases and also lipolysis inhibition through adipose triglyceride lipase (ATGL) suppression (25-27).

Intermittent $\mathrm{HH}$ exposures were experienced on pilot and air force army in order treat them to get adaptation in hypoxia condition. However, beside hypoxia adaptation, this training may disturb some metabolism that affect their health. According to our study, intermittent $\mathrm{HH}$ exposures induce triacylglycerol synthesis in the liver. This condition could contribute to some diseases in the future, such as fatty liver disease and metabolic syndrome $(28,29)$. Another disease that has similar pathogenesis like intermittent hypoxia is obstructive sleep apnoea (OSA) is an obstruction of the upper airway during sleep and occur temporal deprivation of oxygen in blood. Clinical studies have reported that a combination of OSA and obesity promotes excessive fat accumulation and progression of non-alcoholic fatty liver disease (NAFLD) $(30,31)$. 
Therefore, this study is a preliminary study to reveal the effect of exposure to intermittent $\mathrm{HH}$ as intermittent hypoxia model on metabolic changes in the liver, especially triacylglycerol synthesis. So, according to results of this study we can take prevention step or therapy to overcome some diseases associated to intermittent hypoxic condition.

In summary, intermittent hypobaric hypoxia exposures will increase triacylglycerol level in rat liver, supported by

\section{References}

1. Alves-Bezerra M, Cohen DE. Triglyceride metabolism in the liver. Compr Physiol. 2018;8(1):1-8.

2. Lieberman M, Peet A. Marks' basic medical biochemistry: a clinical approach. 5th edition. Philadelphia: Wolters Kluwer; 2018. 433-471.

3. Mylonis I, Simos G, Paraskeva E. HypoxiaInducible Factors and the Regulation of Lipid Metabolism. Cells. 2019;8(3):214.

4. Krishnan J, Suter M, Windak R, Krebs T, Felley A, Montessuit C, et al. Activation of a HIF1 $\alpha$-PPAR $\gamma$ Axis Underlies the Integration of Glycolytic and Lipid Anabolic Pathways in Pathologic Cardiac Hypertrophy. Cell Metab. 2009;9(6):512-24.

5. Koh MY, Spivak-Kroizman T, Powis G. HIF1 regulation: not so easy come, easy go. Trends Biochem Sci. 2008;33(11):526-34.

6. Weidemann A, Johnson RS. Biology of HIF1a. Cell Death Differ. 2008;15(4):621-7.

7. Shen G, Li X. The Multifaceted Role of Hypoxia-Inducible Factor 1 (HIF1). In: Lipid Metabolism, Hypoxia and Human Diseases, Jing Zheng J, Zhou, Ch. IntechOpen; 2017. p. 1-29.

8. Sarkar S, Banerjee PK, Selvamurthy W. High altitude hypoxia: An intricate interplay of oxygen responsive macroevents and micromolecules. Mol Cell Biochem. 2003;253(1-2):287-305.

9. Tirosh O. Hypoxic Signaling and Cholesterol Lipotoxicity in Fatty Liver Disease Progression. Oxid Med Cell Longev. 2018;2018:2548154.

10. Wald A, Fay C, Gleich R. Introduction to Aviation Management. 2010.

11. Maresh RW, Woodrow AD, Webb JT. Handbook of Aerospace and Operational Physiology, 2nd Edition. 2018. 1-842 p. the increasing of HIF- $1 \alpha$ and PPAR- $\gamma$ mRNA expression in early phase exposure of hypobaric hypoxia that act as transcription factor to promote triacylglycerol synthesis.

\section{Acknowledgements}

This study was funded by Hibah Publikasi Terindeks Internasional Q3 (PUTI Q3) 2020 with No. NKB-4398/UN2.RST/HKP.05.00/2020 from Directorate of Research and Community Services Universitas Indonesia.

12. Livak KJ, Schmittgen TD. Analysis of relative gene expression data using real-time quantitative PCR and the 2(-Delta Delta C(T)) Method. Methods. 2001;25(4):402-8.

13. Triantafyllou E-A, Georgatsou E, Mylonis I, Simos G, Paraskeva E. Expression of AGPAT2, an enzyme involved in the glycerophospholipid/triacylglycerol biosynthesis pathway, is directly regulated by HIF-1 and promotes survival and etoposide resistance of cancer cells under hypoxia. Biochim Biophys Acta Mol Cell Biol Lipids. 2018;1863(9):1142-52.

14. Mylonis I, Sembongi H, Befani C, Liakos P, Siniossoglou S, Simos G. Hypoxia causes triglyceride accumulation by HIF-1-mediated stimulation of lipin 1 expression. J Cell Sci. 2012;125(Pt 14):3485-93.

15. Finck BN, Gropler MC, Chen Z, Leone TC, Croce MA, Harris TE, et al. Lipin 1 is an inducible amplifier of the hepatic PGC-1 $\alpha /$ PPAR $\alpha$; regulatory pathway. Cell Metab. 2006;4(3):199210.

16. Viscor G, Torrella JR, Corral L, Ricart A, Javierre C, Pages T, et al. Physiological and Biological Responses to Short-Term Intermittent Hypobaric Hypoxia Exposure: From Sports and Mountain Medicine to New Biomedical Applications. Front Physiol. 2018;9:814.

17. Zhao Y-Z, Liu X-L, Shen G-M, Ma Y-N, Zhang F-L, Chen M-T, et al. Hypoxia induces peroxisome proliferator-activated receptor $\gamma$ expression via HIF-1-dependent mechanisms in HepG2 cell line. Arch Biochem Biophys. 2014;543:40-7.

18. Shi H, Luo J, Zhu J, Li J, Sun Y, Lin X, et al. PPAR $\gamma$ Regulates Genes Involved in 
Triacylglycerol Synthesis and Secretion in PPAR Res. 2013;2013:310948.

19. Chawla A, Schwarz EJ, Dimaculangan DD, Lazar MA. Peroxisome proliferator-activated receptor (PPAR) gamma: adipose-predominant expression and induction early in adipocyte differentiation. Endocrinology. 1994;135(2):798800.

20. Rosen ED, Sarraf P, Troy AE, Bradwin G, Moore K, Milstone DS, et al. PPAR $\gamma$ Is Required for the Differentiation of Adipose Tissue In Vivo and In Vitro. Mol Cell. 1999;4(4):611-7.

21. Krishnan J, Suter M, Windak R, Krebs T, Felley A, Montessuit C, et al. Activation of a HIFlalpha-PPARgamma axis underlies the integration of glycolytic and lipid anabolic pathways in pathologic cardiac hypertrophy. Cell Metab. 2009;9(6):512-24.

22. Matsusue K, Haluzik M, Lambert G, Yim S$\mathrm{H}$, Gavrilova O, Ward JM, et al. Liver-specific disruption of PPARgamma in leptin-deficient mice improves fatty liver but aggravates diabetic phenotypes. J Clin Invest. 2003;111(5):737-747.

23. Reddy JK, Rao MS. Lipid metabolism and liver inflammation. II. Fatty liver disease and fatty acid oxidation. Am J Physiol Gastrointest Liver Physiol. 2006;290(5):G852-8.

24. Etesami B, Ghaseminezhad S, Nowrouzi A, Rashidipour M, Yazdanparast R, et al. Investigation of 3T3-L1 Cell Differentiation to Adipocyte, Affected by Aqueous Seed Extract of Phoenix Dactylifera L. Reports Biochem Mol Biol. 2020;9(1):14-25.
25. Huang D, Li T, Li X, Zhang L, Sun L, He X, et al. HIF-1-Mediated Suppression of Acyl-CoA Dehydrogenases and Fatty Acid Oxidation Is Critical for Cancer Progression. Cell Rep. 2014;8(6):1930-1942.

26. Liu Y, Ma Z, Zhao C, Wang Y, Wu G, Xiao $\mathrm{J}$, et al. HIF-1 $\alpha$ and HIF- $2 \alpha$ are critically involved in hypoxia-induced lipid accumulation in hepatocytes through reducing PGC-1 $\alpha$-mediated fatty acid $\beta$-oxidation. Toxicol Lett. 2014;226(2):117-23.

27. Han JS, Lee JH, Kong J, Ji Y, Kim J, Choe SS, et al. Hypoxia Restrains Lipid Utilization via Protein Kinase A and Adipose Triglyceride Lipase Downregulation through HypoxiaInducible Factor. Mol Cell Biol. 2019;39(2):e00390-18.

28. Suzuki T, Shinjo S, Arai T, Kanai M, Goda N. Hypoxia and fatty liver. World J Gastroenterol. 2014;20(41):15087-15097.

29. Savage DB, Semple RK. Recent insights into fatty liver, metabolic dyslipidaemia and their links to insulin resistance. Curr Opin Lipidol. 2010;21(4):329-36.

30. Aron-Wisnewsky J, Minville C, Tordjman J, Lévy P, Bouillot J-L, Basdevant A, et al. Chronic intermittent hypoxia is a major trigger for nonalcoholic fatty liver disease in morbid obese. $\mathbf{J}$ Hepatol. 2012;56(1):225-33.

31. Sookoian S, Pirola CJ. Obstructive Sleep Apnea Is Associated with Fatty Liver and Abnormal Liver Enzymes: a Meta-analysis. Obes Surg. 2013;23(11):1815-25. 